\title{
Synthetic Peptide Vaccines
}

\author{
Alexandr A. Moisa and Ekaterina F. Kolesanova \\ Institute of Biomedical Chemistry, Russian Academy of Medical Sciences \\ Moscow, \\ Russia
}

\section{Introduction}

Vaccination was discovered more than 200 years ago and quickly distributed around the whole Europe despite of the fact that mechanisms of protective effects of vaccines remained unclear for a long time. New vaccines appeared only at the end of XIX century and mainly during the last century after detailed studies of infectious processes, microorganisms inducing these infections, and mechanisms of immune defense. During this period many effective vaccines were developed; they controlled and even totally eliminated some dangerous infectious diseases (Makela, 2000). Now about 40 human diseases are controlled by vaccination (Uchaikin \& Shamsheva, 2001). However, for some infections vaccine prophylaxis and vaccine therapy have not been developed yet. These include AIDS and hepatitis C (Barrett \& Stanberry, 2009). Situation with these infections is complicated by lack of effective therapeutics, causing full elimination of the human immunodeficiency virus causing AIDS and therapeutics, which would be effective in all patients infected with hepatitis C virus (HCV) (Barrett \& Stanberry, 2009). It results in the high chronization degree of these infections (almost 100\% in the case of HIV infection and $70-80 \%$ in the case of HCV), which basically become lethal ones (Barrett \& Stanberry, 2009). Numerous efforts to develop vaccines against these diseases still remain unsuccessful; however, problems associated with the development of such vaccines stimulated large-scale studies of the interaction of infectious agents with the immune system, mechanisms of the immune response, structural basis of immunogenicity and antigenicity, methodology and technology for the development of new generation vaccines.

Traditional vaccines are subdivided into alive (attenuated microorganisms or viral cultures), dead, or corpuscular (inactivated infectious agents) and subunit, or chemical vaccines (individual immunogenic components of infective agents) (Uchaikin \& Shamsheva, 2001). The latter vaccines are free from side effects that appear after inoculation of the whole pathogenic agents. Traditional technology has been employed for the development of effective vaccines against many infections (Uchaikin \& Shamsheva, 2001); however, now this technology tends to be avoided in many cases because the preparation and use of such vaccines is associated with some problems (Liljeqvist \& Stahl, 1999), including:

- expensive cultivation of pathogenic bacteria, viruses or protozoa for industrial production of vaccines or immunogenic components;

- $\quad$ risk of infectious agent leaks; 
- $\quad$ side effects during administration; first of all, increased reactogenicity, which cannot be excluded even in the case of subunit vaccines;

- $\quad$ expensive purification and detoxification of vaccine products;

- $\quad$ high genetic variability of an infectious agent; this complicates the detection of chemical components, which can induce an immune response against all its strains;

- significant structural changes of an infectious agent during its life cycle in the host organism that lead to the changes of its antigenic properties.

Solution of these problems requires elaboration of novel approaches to vaccine development based on knowledge of an antigenic structure of a pathogen, immune response of the host organism to the pathogen or its components, and mechanisms responsible for the modification of strength and direction of this response. Such combined approach that includes the arsenal of methods of bioinformatics, molecular biology, organic chemistry, experimental and clinical immunology is known as "reverse vaccinology". It is aimed at the identification, study of antigenic and immunogenic properties, construction and production of highly purified preparations of novel recombinant and synthetic immunogens and their use for the development of new generation vaccines (Rappuoli, 2001). Synthetic peptide vaccines considered in this review belong to vaccines developed by this approach. Here we do not discuss problems of the development of anticancer vaccines, because of special approaches required for that. One can address available papers, including reviews (Palena et al, 2006, Machiels et al, 2002, Garg et al., 2010) that describe this question.

\section{What are peptide vaccines and what are their advantages?}

Synthetic peptide vaccines represent fragments of protein antigen sequences, which are synthesized from amino acids and assembled into a single molecule or a supramolecular complex or just mechanically mixed; they are recognized by the immune system and induce the immune response (Sesardic, 1993). This immune response may involve either cytotoxic T-cells or B-cells (i.e. directed to elaboration of specific antibodies) or combine both possible pathways (Bijker et al., 2007). Fragments of protein molecules exhibiting B- and/or Tepitope activity are the main components of peptide vaccines, which determine the direction and specificity of the immune response. Such vaccines may also contain some individual compounds or supramolecular complexes (e.g. micelles, liposomes, polymer particles, etc.), which can nonspecifically or specifically activate certain stages of the immune response to peptides and therefore potentiate this response (Vogel \& Alving, 2002). Increase in chemical stability of peptides is achieved by their attachment to carriers, which simultaneously act as activators of the immune response (Aguilar \& Rodriguez, 2007).

Peptide vaccines are characterized by the following advantages over traditional vaccines based on dead pathogens, and also subunit and recombinant vaccines (Ben-Yedidia \& Arnon, 1997; van der Burg et al., 2006):

- $\quad$ Relatively inexpensive and safe production technologies.

- Ability to induce the immune response to those structural elements of a protein antigen, which exhibit weak immunogenicity within the whole antigen molecule.

- High standardization.

- $\quad$ Lack of components possessing high reactogenicity (lipopolysaccharides, toxins). 
- Possibility of removal of antigen fragments exhibiting allergenicity and cross-reactivity to own molecules of the vaccinated organism.

- Possibility of conjugation of various peptides from different antigens to the same carrier.

\section{Steps for the synthetic peptide vaccine development}

The development of a candidate synthetic peptide vaccine includes the following steps (Rappuoli, 2001, Sobolev et al., 2005):

1. Selection of immunoactive peptide fragments of protein antigen(s) of an infectious agent and construction of a peptide antigen (or several antigens).

2. Chemical synthesis of peptide antigens and their conjugation (if necessary) to a carrier.

3. Immunogenicity testing of resultant constructs on laboratory animals, determination of specificity of antibodies (elaborated to these constructs) and their protective properties.

4. Preclinical trials of selected antigens.

5. The development of the candidate vaccine and laboratory technology for its production and elaboration of samples for testing.

6. Preclinical and clinical trials of the candidate vaccine samples.

Steps $4-6$ are usually determined by sanitary rules and methodical instructions approved by the corresponding governmental control services (in Russian Federation: State Sanitary and Epidemiologic Inspection (Sanitary Rules, 1995, 1998; Methodical Recommendations, 1998); in the USA: Food and Drug Administration (FDA)). Steps 1-3 are discussed in this review.

\subsection{Selection of antigenic determinants for immunogenic constructs}

First of all, one should take into account the type of the immune response directed to the pathogen neutralization and providing vaccine therapy and/or vaccine prophylaxis: cytotoxic response realized by specific cytotoxic T-lymphocytes, or specific humoral response, which involves the conversion of B-lymphocytes activated by a particular antigen into plasma cells that generate specific neutralizing antibodies (Sobolev et al., 2005). General features of mechanisms responsible for the formation of the specific immune response to various foreign antigens are comprehensively considered in textbooks (Male et al., 2006, Abbas \& Lichtman, 2011). Taking into account these common mechanisms, vaccines directed to the generation of cytotoxic immune response should contain cytotoxic T-epitopes as obligatory components, which are often supplemented by class 1 T-helper epitopes (van der Burg et al., 2006). Vaccines that induce antibody formation should contain B-epitopes and T-helper epitopes as obligatory components (van der Burg et al., 2006). It is essential that the B-epitope components of such vaccines should originate from antigens from virulent strains and the generated antibodies should suppress virulence (Sesardic, 1993).

If antigens and virulence factors of an infectious agent remain unknown, it is possible to predict them by means of the "reverse vaccinology", which employs computer analysis of biopolymer structures (first of all their nucleotide and amino acid sequences of genome and proteome, respectively). The technology of this process has been highlighted in the reviews (Rappuoli, 2001, Sobolev et al., 2005, Barocchi et al., 2007). In order to prove the antigenicity and virulence of predicted protein molecules they are expressed and tested for the 
interaction with antibodies obtained from patients with corresponding infections and for their ability to cause pathological reactions in animals (Rappuoli, 2001). Now, highthroughput screening methods for antigen detection in microorganism proteomes have appeared. These include SERPA technology (SERological Proteome Analysis) and antigenome analysis (Klade, 2002; Ling et al., 2004; Tedeschi et al., 2009,Vytvytska et al., 2002, Målen et al., 2008; Glowalla et al., 2009; Meinke et al., 2005; Felgner et al., 2009; Fritzer et al., 2010). The first method consists in the separation of protein components of the cultivated infectious agent by two-dimensional electrophoresis followed by subsequent visualization of antigenically active proteins by immunoblotting with antibodies from sera of patients with corresponding diseases (Målen et al., 2008; Glowalla et al., 2009; Meinke et al., 2005; Felgner et al., 2009; Fritzer et al., 2010). The second approach includes preparation (by means of heterologous expression) of a library of proteins and their fragments encoded by the library of genome fragments of the infectious agent followed by subsequent testing of expressed proteins for antigenicity (evaluated by interaction with antibodies from sera of infected patients) and then for immunogenicity in experiments by immunizing laboratory animals (Felgner et al., 2009; Fritzer et al., 2010; Meinke et al., 2005). Antigenomic analysis excludes the cultivation of a pathogenic organism of interest; it is applicable in the case of microorganisms with small and completely sequenced genomes. To the contrary, SERPA technology is suitable for the determination and characterization of primary structures of the most diagnostically and therapeutically important antigens of infectious agents with incompletely sequenced genomes.

The next task consists in the identification of peptides corresponding to B- and T-epitopes. If tertiary structure of the peptide antigen and/or its sites involved in the binding with antibodies neutralizing its virulent properties are known, the task implies the selection and design of a peptide (or peptides) that is the best model of the already known B-epitope (Rodriguez et al., 2007, Haro et al., 2003). However, tertiary structures of antigens may be unknown; and also, this approach detects only B-epitopes, but not T-epitopes, recognized as linear peptides. Frequently, most probable B- and T-epitope selection is performed via the antigen amino acid sequence analysis with the help of bioinformatics approaches. The principal technology of this process has been well described in many reviews (Sobolev et al., 2005, Sobolev et al., 2003, He et al., 2010). It should be noted that computer-based epitope prediction capabilities are constantly extended: appearance of new information on mapped $\mathrm{B}$ - and T-epitopes results in the more exact specification of corresponding patterns and, consequently, in increased effectiveness of corresponding program products. New, more convenient interfaces are developed for servers containing epitope databases and prediction tools; the development of integrated servers allows to search for possible B- and T-epitopes and combine them into putative immunogenic constructions at one place (Sieker et al., 2009; Wiwanitkit, 2009; MacNamara et al., 2009; Lin et al., 2008; Perry et al., 2008; Roggen, 2006; Tian et al., 2009; Schuler et al., 2007).

However, accuracy of prediction of B- and T-helper epitopes from antigen amino acid sequences remains rather low, and many researchers prefer experimental identification of these epitopes (especially taking into account existing methods of high-throughput screening). Peptide scanning by means of partially overlapping fragments of protein antigen amino acid sequences obtained by multiple parallel synthesis allows to map both linear Bepitopes and also helper and cytotoxic T-epitopes (Castric \& Cassels, 1997; Tribbick, 2002). B-epitopes are detected by testing peptides for their interaction with antisera obtained 
against the whole protein antigen and also sera of infected patients (there are many examples of such studies, for example, antigenic mapping of $\mathrm{HCV}$ envelope proteins (Kuzmina et al., 2009; Olenina et al., 2002)). Besides chemical synthesis, fragments of antigen amino acid sequences for B-epitope mapping are also obtained by genetic engineering approach: by means of construction of expression libraries of fragments as chimeras with easily expressed and purified proteins (Bongartz et al., 2009). Peptides of various lengths (from 6 to 20 and even more residues) are used for antigen scanning for B-epitopes; however, it should be noted that peptides longer than 10 residues may contain more than one linear B-epitope (Olenina et al., 2002). Besides the determination of linear B-epitopes attempts are undertaken to map and model conformational epitopes by synthetic and also phage display combinatorial peptide libraries that cover a large number of amino acid sequences from 6 to 15 residues (Pereboeva et al., 2000). In addition, B-epitopes may be determined by means of mass-spectrometry analysis of antigen-antibody complexes via the determination of an antigen site protected against proteolysis or modification by an antibody paratope (Castric \& Cassels, 1997; Lu et al., 2009). Fragments of antigen molecules exhibiting T-epitope activity are detected by their ability to induce proliferation of Tlymphocytes in culture (Ahmed \& Maeurer, 2009). Cytotoxic T-epitopes have a limited length (8-11 residues) and must have free $\mathrm{N}$-terminal amino and C-terminal carboxyl groups; it is determined by the structure of the MHC I binding pocket. In the case of helper T-epitope determination, longer peptides, often with amidated C-terminal carboxyl groups, are used (Tribbick, 2002). The type of helper epitope activity (Th1 or Th2) is determined by ELISPOT technology. This technology allows large-scale screening of peptides, putative Thelper epitopes, via the determination of the cytokine profile (gamma-interferon, interleukins 2, 4, 10, etc) secreted by T-lymphocytes stimulated by corresponding peptides (Kalyuzhny, 2005; Wulf et al., 2009). Peptide vaccines usually contain such T-helper epitope, which exhibits affinity towards several most widespread (in a given population) Human Leukocyte Antigen (HLA) alleles (so-called universal, or promiscuous T-epitope), or an antigen fragment containing several overlapping T-epitopes of different specificity towards HLA (Sobolev et al., 2005, Panina-Bordignon et al., 1989; Jackson et al., 2002). Several cytotoxic T-epitopes with different specificity towards HLA are included into candidate peptide vaccines for induction of cytotoxic response (Bermúdes et al., 2007; Lauer et al., 2004).

\subsection{Construction of peptide immunogen}

Formation of a single immunogenic construction from predicted or experimentally determined B- and T-epitopes provides optimal recognition of all the components of this construction by the immune system. For example, the integration of a linear B-epitope and a helper T-epitope in a single molecule results in their penetration into the same Blymphocyte, which will be converted into a plasma cell producing antibodies of a desired specificity (Moss et al., 2007). B- and T-epitopes may be located far away from each other in a parent protein antigen molecule; moreover, they may originate even from different proteins of the infectious agent and even from different microorganisms. For example, the universal human T-helper epitope of tetanus toxin, QYIKANSKFIGITE, is frequently used in immunogenic constructions in combinations with various peptide B-epitopes for high population coverage of a candidate vaccine (Panina-Bordignon et al., 1989). Combination of 
a fragment, which is supposed to induce a specific antibody, but is characterized by weak (if any) immunogenicity within the whole protein antigen, with the universal T-helper epitope allows the induction of such specific humoral response in the vaccinated organism that could not be achieved by the immunization with the whole antigen. It is one of advantages of peptide vaccines. Insertion of a short flexible linker between B- and T-epitopes provides a free rotation of the B- and T-helper parts versus each other and therefore promotes independent recognition by corresponding receptors of immunocompetent cells (Moss et al., 2007). In some cases overlapping B- and T-helper epitopes are used as they are located in the protein antigen molecule (e.g. synthetic peptide immunogens from protein VP1 of foot-andmouth disease virus (Kupriianova et al., 2000)).

Synthetic immunogenic constructs can be represented by both linear oligopeptides and more complex structures such as branched dendrimers (so-called lysine "trees") (Tam, 1988; Van Regenmortel \& Muller, 1999), cyclic or linear unbranched oligomers conjugated (via their side chain functional groups) with either individual B- and T-epitopes or such constructs as T-epitope-linker-B-epitope/B-epitope-linker-T-epitope (Jackson et al., 2002). Complex structures are less sensitive to proteolysis and therefore they have higher stability during administration to the body and form higher local concentrations of the immunogen (Sobolev et al., 2005). However, such structures are more difficult to obtain; in addition, their complex surface structure can interfere with the recognition of individual linear B-epitopes included into these constructs (Van Regenmortel \& Muller, 1999). Optimal co-location of B- and T-epitopes is selected experimentally by comparing the immugenicity of constructs with different structures (Van Regenmortel \& Muller, 1999). A general principle of the effective immune response to B-epitope consists in its close proximity to Thelper epitope(s). Binding of the B-epitope to a B-lymphocyte receptor seems to protect the neighboring T-helper epitope against endosomal cleavage (Moss et al., 2007).

Synthetic peptide vaccines based on cytotoxic and Th1-epitopes represent mechanical mixtures of peptides corresponding to various T-epitopes from one or several antigens of an infectious agent (Jackson et al., 2002). The design of monomolecular constructs is not required because in contrast to the B-T-epitope construction these T-epitopes can independently bind to various cells of the immune system.

The monomolecular immunogenic constructions can also include components with adjuvant functions (see below).

\subsection{Immunogen synthesis}

Peptide components for synthetic vaccines are obtained by means of solid phase peptide synthesis and peptide synthesis in solution (Sobolev et al., 2005, Sieker et al., 2009; Jackson et al., 2002, Tam, 1988; Van Regenmortel \& Muller, 1999). In the case of constructs that include B- and T-helper epitopes representing rather long peptides (exceeding 20 residues) an automated solid phase synthesis or a combination of solid phase synthesis of separate immunogen fragments followed by their condensation into a single peptide in solution are preferable (Lloyd-Williams et al., 1997; Bruckdorfer et al., 2004; Mitsuaki et al., 1987; Rinnova et al., 1999). Solid phase peptide synthesis developed by Merrifield in the beginning of 1960th, now represents rather routine procedure due to numerous studies and automation of this process (Lloyd-Williams et al., 1997). The major advantage of solid phase 
synthesis over synthesis in solution consists in that there is no need in the purification of a resultant product after each round of peptide chain elongation. The product remains covalently bound to a polymer support up to the end of synthetic procedure, and unreacted components, activators and improper products are washed away by a solvent flow. It significantly accelerates the solid phase protein synthesis compared to the synthesis in solution (Bruckdorfer et al., 2004). Use of microwave irradiation significantly accelerates the solid phase synthesis process and increases its efficiency: synthesis of peptides of 40 residues long takes less than one day and results in good yields. It is especially useful for the synthesis of peptides, which tend to aggregate on the support (Sabatino \& Papini, 2008). Of course, synthesis of each peptide requires experimental selection of the most effective protocol and initial amino acid derivatives, which allow to obtain the final product with a maximal yield (Lloyd-Williams et al., 1997). Now the most popular peptide synthesis employs amino acid derivatives protected at alpha-amino group with 9fluorenyl(methoxycarbonyl) (FMOC). In contrast to synthesis using tertbutyl(oxycarbonyl)(BOC)-amino acid derivatives it does not require the use of such strong acid as HF to cleave the synthesized peptide from the support at the end of the process. FMOC-amino acids are preferably used in large-scale peptide synthesis that may yield tens and even hundred kilograms of peptides (Bruckdorfer et al., 2004). Since it is difficult to obtain long peptides (exceeding 30 residues) with good yield and separate them from contaminants differing by $1-2$ residues, such peptides are synthesized as $2-3$ fragments with protected side chain functional groups and then these fragments are linked together (in solution) into a single molecule (Mitsuaki et al., 1987; Rinnova et al., 1999). The same approach is used for conjugation of B-T-epitope constructions or individual epitopes with lysine dendrimers, cyclic or linear oligomer matrix structures. Methods of chemoselective cross-links used for conjugation of peptides with oligomer carriers are discussed elsewhere (Jackson et al., 2002). Non-disturbance of epitope structures during cross-linking is achieved via the introduction of additional modifiable groups or amino acid residues into synthesized peptides. Most frequently, conjugation is performed by thioalkylation (in this case cysteine residue is included into one component of the construct, whereas monochloroacetyl or maleimide group is included into another component), hydrazone or oxime formation (serine residue is included into one component, in which the $\mathrm{CH}_{2} \mathrm{OH}$ group is oxidized to $\mathrm{CHO}$ by periodic acid, while monohydrazide of succinic or benzoic acid or aminooxyacetic acid residue is included into another component), and formation of thiazolidine or oxazolidine cycle (in this case the $\mathrm{CH}_{2} \mathrm{OH}$ group of serine residue included into one component is oxidized to $\mathrm{CHO}$ and additional serine or cysteine residue is included into another component). In addition, some companies (e.g. Novabiochem and Bachem, both from Switzerland) produce supports for solid phase peptide synthesis with preformed lysine dendrimers, on which peptide synthesis can be performed.

\subsection{Adjuvants for peptide vaccines}

Formation of strong and long-term specific immune response to antigens is an important task for creation of any vaccine. It is achieved by an additional nonspecific stimulation of the immune system cells, specific targeted antigen delivery to the immunocompetent cells and their constant activation by the antigen due to its depositing and protection against protease cleavage. These functions are attributed to adjuvants (from Latin adjuvans, adjuvantis: aiding, helping), which are included into vaccine preparations (Aguilar \& Rodriguez, 2007). In 
vaccines prepared from attenuated and killed infectious agents structural elements of the microorganisms such as cell walls, membranes and their components (polysaccharides, lipopolysaccharides, phospholipids, etc.) play the adjuvant role (Uchaikin \& Shamsheva, 2001, Aguilar \& Rodriguez, 2007). Subunit vaccines contain added adjuvants, which promote the depositing of antigens (via their adsorption) and nonspecific stimulation of the immune response (lymphocyte and macrophage attraction to the injection site due to the inflammatory reaction development); usually aluminium salts or hydroxide are used for this purpose (Aguilar \& Rodriguez, 2007; Uchaikin \& Shamsheva, 2001). Adjuvant selection becomes especially important during development of synthetic peptide vaccines, because peptides are usually well soluble in aqueous media, readily subjected to proteolysis and are not deposited at the administration site. Peptide constructs are targeted to the activation of immune response of a narrow specificity, and they do not provide attraction and activation of cells participating in the nonspecific immune response, which potentiate and direct the specific response. Aluminum hydroxide and salts poorly adsorb peptides, weakly activate immunocompetent cells and do not potentiate the immune response to peptide antigens (Jackson et al., 2002). Search for new adjuvants for peptide vaccines against human infectious diseases includes adjuvants approved to animal use and also immunomodulators (Aguilar \& Rodriguez, 2007, Jackson et al., 2002).

Oil-based adjuvants, for example, Freund's complete adjuvant (which contains a suspension of killed Mycobacterium tuberculosis cells or their lipopolysaccharides in a mineral oil with lanolin) are used in laboratory studies of immunogenicity on animals for a long time. However, Freund's adjuvant is rather toxic, exhibits high reactogenicity and can induce formation of necrotic ulcers at the injection site (Allison \& Byars, 1991). Now less toxic and reactogenic oil-based adjuvants (Montanide series) have been developed; they are used in some peptide vaccines that are under clinical trials (Ahmed \& Maeurer, 2009; Roestenberg et al., 2008).

Saponins (e.g., QuilA, an extract from Quillaja saponaria, in which 23 different saponins have been identified), plant glycosides with surfactant properties, which form micelles in solution, are also used as adjuvants. QuilA is too toxic for use in humans, but its fraction QS21, which is less toxic and induces an effective T-cell response against antigens, is considered as a prospective adjuvant for peptide vaccines (Allison \& Byars, 1991; Kensil, 1996; Takahashi et al., 1990). Saponins are used as adjuvants in the immunostimulating complexes (abbreviated as ISCOMs), which represent mixed micelles of saponin and cholesterol of $40 \mathrm{~nm}$ in diameter where hydrophobic and amphipathic antigens are inserted. ISCOMs represent a convenient system for antigen delivery to antigen presenting cells; these particles can penetrate into such antigen-presenting cells as dendritic cells and macrophages, and hence increase the efficiency of antigen presentation (Allison \& Byars, 1991; Singh et al., 2006).

Improvement in peptide antigen transport to antigen presenting cells also occurs using the polycations poly-L-lysine, poly-L-arginine and chitosan as adjuvants (Schlaphoff et al., 2007; Svirshchevskaya et al., 2009). Effectiveness of the polymeric polycation polyoxidonium (which has been shown to nonspecifically activate cell immune response (Khaitov \& Pinegin, 2005)) as the adjuvant for synthetic peptide vaccines is still questionable (Olenina et al., 2003).

Currently adjuvants synthesized on the basis of pathogen-associated unique highly conserved molecular structures are widely used; they do not have analogues in 
macroorganisms and trigger nonspecific immune response via pattern-recognizing receptors (e.g. Toll like receptors) [Düesberg et al., 2002; Chua et al., 2007; Jackson et al., 2004]. Dipalmitoyl glyceryl-S-cysteine (Pam 2 Cys) (Düesberg et al., 2002; Chua et al., 2007; Jackson et al., 2004; Deliyannis et al., 2006), a synthetic analogue of the lipid fragment of macrophage activating lipopeptide-2 isolated from Mycoplasma fermentans membranes (Zeng et al., 2002) is one of such structures. Pam ${ }_{2}$ Cys has been used in some candidate synthetic peptide vaccines against hepatitis $C$ virus; these vaccines consist of cytotoxic HLA-A2-specific Tepitope of the HCV NS5B protein or of highly immunogenic hypervariable region 1 of $\mathrm{HCV}$ E2 envelope protein and a foreign CD4+ T-helper epitope (Engler et al., 2004; Torresi et al., 2007; Chua et al., 2008). Synthetic peptide constructs also contain the other lipid group, $\mathrm{Pam}_{3}$ Cys, which represents an N-terminal fragment of E. coli lipoprotein (Zeng et al., 2000; Müller et al., 2002). The immunogenic constructs based on the peptide covalently linked to Pam $_{3}$ Cys induce an effective immune response after both parenteral and intranasal administration; the raised protective antibodies belong to immunoglobulin A type (Müller et al., 2002), which are important components of the mucosal immune response.

Frequently, peptide constructs containing fatty acid residues and also hydrophobic peptides are included into liposomes. Liposome-associated antigens are protected against proteolysis, they arrive directly to the antigen-presenting cells and this potentiates the immune response (Engler et al., 2004; Kaplun et al., 1999; Scheerlinck \& Greenwood, 2006, 2008). Besides antigens, liposomes also contain proteins promoting liposome fusion with cell membranes, such as influenza virus hemagglutinin; such particles are known as virosomes (Kaplun et al., 1999; Scheerlinck \& Greenwood, 2008). Virosomes use routes that are natural for viral particles and the antigen fragment is exposed on the surface of the antigen-presenting cells in the complex with MHC II (i.e. in the form recognized by T-helpers). Antigen incorporation into nanoparticles of $20-40 \mathrm{~nm}$ in size (virosomes, liposomes, ISCOMs) improves its presentation because such particles are readily absorbed by antigen-presenting dendritic cells (Jackson et al., 2004; Scheerlinck \& Greenwood, 2006, 2008).

Besides liposomes and ISCOMs antigens may be also incorporated into biodegradable polymeric microspheres for storage and protection against proteolysis. Such microcapsules (size less than $10(\mathrm{mu}) \mathrm{m}$ ) that consist of polylactide, polyglycolide or their copolymer may be used for peroral antigen administration because they are insoluble in gastric juice and may provide gradual antigen release (Eldridge et al., 1991; Cox et al., 2006; Scheerlinck \& Greenwood, 2006).

\subsection{Evaluation of efficiency and protectivity of the immune response to synthetic peptide immunogens}

Studies of peptide constructs begin with the determination of their immunogenicity (i.e. their ability to induce the immune response programmed during the design of these constructs) (Sobolev et al., 2005, Sobolev et al., 2003, Jackson et al., 2002). If a peptide immunogen includes B- and T-helper epitopes, it should induce production of antibodies against its B-epitope and also against the protein, which "borrowed" the fragment corresponding to this B-epitope; usually such experiments are performed on laboratory animals. The higher the proportion of animals developed such immune response (among total number of immunized animals) the more universal T-helper epitope included into the construct is. Immunogenicity of a mixture of peptides corresponding to cytotoxic T-epitopes 
is initially elucidated by appearance of cytotoxic T-lymphopcytes of a certain specificity in immunized animals (Kalyuzhny, 2005; Wulf et al., 2009). Subsequently, effectiveness of the cytotoxic immune response is evaluated in a mixed cell culture by the degree of infected cell killing by cytotoxic T-lymphocytes obtained from immunized animals or cell cultures stimulated by the investigated peptide immunogens (Lauer et al., 2004; Schlaphoff et al., 2007; Takahashi et al., 1990). Protectivity of the specific humoral response induced by peptide immunogen administration is determined by the neutralizing effect of antibodies on the penetration of an infectious agent to the target cell or by inactivation of a toxin produced by the infectious agent (Sobolev et al., 2005, Sobolev et al., 2003; Law et al., 2008). If animals are also susceptible to this disease an investigation of the protective effect of the immunization by the peptide antigen is performed on animals. Strains of small rodents are the most convenient animal models from the viewpoint of maintenance. However, there are situations when no laboratory animal is susceptible to a certain disease. In such cases severe combined immunodeficiency (SCID) mice with xenotransplanted human cells or tissues are used: in the case of malaria these are SCID mice with transplanted human erythrocytes (Badell et al., 2000), in the case of hepatitis C these are SCID mice with transplanted human hepatic tissue (Guévin et al., 2009; Zhu et al., 2006). Alternatively, researchers limit their experiments by testing protectivity of the immune response in cell cultures. For example, testing of virus neutralizing activity of antibodies produced in response to hepatitis $C$ virus $(\mathrm{HCV})$ antigens is performed in experiments by blockade of the entry of the virus or viruslike particles carrying HCV envelope proteins on their surfaces into primary hepatocytes or into hepatoma cell culture (Law et al., 2008).

It should be noted that not only the strength of the protective immune response but also its duration after the last immunogen administration is crucial. If an infectious agent exhibits high genetic variability, it is important to elucidate whether the immune response to a particular peptide immunogen is strain or isolate-specific. Only after this step of studies the synthetic peptide immunogenic construction may be submitted to preclinical and clinical trials (Rappuoli, 2001, Sobolev et al., 2005, Sobolev et al., 2003).

\section{Examples of synthetic vaccines reaching stages of clinical trials}

\subsection{Peptide vaccines against malaria}

Development of peptide vaccines against malaria started in 1970th and in spite of first unsuccessful attempts it is still considered as a perspective direction (Epstein et al., 2007). Malaria is caused by Plasmodium parasites, which undergo several developmental stages in the human body and each stage of its development is characterized by different protein and therefore antigenic structures. Forty perspective protective Plasmodium antigens have been identified and they are used for the development of various types of anti-malaria vaccines targeted to various stages of the parasite life cycle. Interest in the development of peptide vaccines is determined by genetic and therefore antigenic differences in local populations of Plasmodium; this does not allow to form the isolate-nonspecific protective immune response during administration of the whole infectious agent or its protein antigens than belong to one of many strains (Takala \& Plowe, 2009). In addition, it is easier to develop a multiantigenic vaccine based on synthetic peptides, which would induce formation of the immune response against various stages of the parasite development (with minimal reactogenicity). 
In 1980, clinical trials of the first synthetic anti-malaria vaccine Spf66 against Pl. falciparum in the asexual stage of development started (Urdaneta et al., 1998). This vaccine consisted of three fragments of three various surface antigens of the merozoite with the repeated PNAN fragment of sporozoite CS protein between them. However, efficiency of Spf66 in clinical trials significantly varied in dependence of geographical regions and subsequent trials were interrupted (Graves \& Gelband, 2007).

Now three candidate vaccines against malaria are under various phases of clinical trials. Two of them contain long ( $>70$ amino acid residues) synthetic peptide immunogens inducing antibody production to two surface Plasmodium proteins at the shizont stage: merozoite surface protein 3 (MSP3) and glutamate rich protein (GLURP). These immunogens are MSP-3-LSP (Long synthetic protein) that represents the MSP-3 fragment including the residues 186-276 [ Bouharoun-Tayoun, 1995] and GLURP-LPS that represents the GLURP fragment including the residues 85-213 (Dodoo et al., 2000; Theisen et al., 2000, 2001). These peptide immunogens were highly conservative for all plasmodium isolates; they induced formation of cytophilic antibodies of IgG1 and IgG3 subclasses; via opsonizing shizonts they attracted monocytes that caused shizont lysis (Theisen et al., 2001; Soe et al., 2004). Phase I clinical trials (Druilhe et al., 2005; Sirima et al., 2009) demonstrated formation of long (at least 1 year) immune response to these vaccines. At the moment Phase IIb clinical trial of the MSP3-LSP vaccine continues (http://www.amanet-trust.org/ext/reports /newsletters/issue23June08.pdf).

Preparations of the virosomal peptide vaccines PEV302 and PEV301 jointly developed by Swiss Tropical Institute and Pevion Biotech Ltd on the basis of fragments of the sporozoite CS protein and apical membrane antigen 1 (AMA-1) are under Phase I clinical trials (AMANET). PEV302 is a 39-mer cyclic peptide containing five highly conservative NPNA repeats of the CS protein; the peptide is conjugated with phosphatidylethanolamine and included into a phosphorlipid particle together with influenza virus hemagglutinin (Okitsu et al., 2007). PEV301 is a similar virosomal preparation that contains another (49-mer) peptide including rather conservative loop I of AMA-1 domain III, also conjugated with phosphatidylethanolamine. It was demonstrated that both peptide containing virosomal preparations induced production of antibodies inhibiting sporozoite invasion of liver cells and erythrocytes (Okitsu et al., 2007; Thompson et al., 2008).

\subsection{Synthetic peptide vaccines against HCV}

Hepatitis C virus (HCV) exhibits extremely high genetic variability and therefore employment of the traditional approach for vaccine development based on attenuated or inactivated virus strain is ineffective in the case of HCV (Barrett \& Stanberry, 2009). This determines the need of nontraditional approaches for the development of anti-HCV vaccines, particularly, synthetic vaccines. HCV envelope proteins are characterized by high variability of their amino acid sequences and the presence of a large number of glycosyl residues similar to those present in host glycoproteins; this complicates the development of effective isolate-nonspecific neutralizing antibody production. At the same time the importance of the cytotoxic immune response in HCV eliminations in patients with spontaneous reconvalescence has been demonstrated (Freeman et al., 2003; Tester et al., 2005). It determined the interest in the development of therapeutic peptide vaccines stimulating the cytotoxic response to the virus. These candidate peptide anti- 
$\mathrm{HCV}$ vaccines represent either a mixture of several peptides or a single multiepitope polypeptide.

\subsubsection{Synthetic peptide vaccines based on CTL epitopes}

IC41 is a therapeutic candidate vaccine developed by Intercell AG (Austria); it contains 5 synthetic peptides ( 2 fragments of the core protein, residues $23-44$ and $132-140$; 2 fragments of the nonstructural protein NS3, residues 1073-1081 and 1248-1261; one fragment of the NS4 protein, residues 1764-1786; all fragments are taken from HCV genotype I and numeration of amino acid residues is shown by the sequence of HCV polyprotein) and poly-L-arginine as the adjuvant stimulating penetration of the peptide antigens into cells. these peptides contain 3 T-helper epitopes (core protein, residues $23-$ 44; NS3, residues 1248-1261; NS4, residues 1767-1786) and five HLA-A2-specific cytotoxic T-epitopes (core protein, residues 35-44 and 132-140; NS3 1073-1081; NS4, residues 1764-1772) (Schlaphoff et al., 2007). The fragments 23-44, 132-140, $1248-$ $1261,1764-1772$ are conservative in various HCV genotypes (the identify of their sequences in the subtypes $1 \mathrm{a}, 1 \mathrm{~b}$, and 2 is not less than $87 \%$ ) (Lauer et al., 2004). The NS3 fragment 1073-1081 differs in various HCV genotypes (the identity did not exceed 15\%); however, vaccine developers used this peptide as one of effective T-epitopes typical for the HCV genotype 1a frequently detected in Europe (Firbas et al., 2006). Phase I clinical trials have shown that the IC41 vaccine induces formation of $\mathrm{HCV}$-specific CD8+ Tlymphocytes in healthy patients and is well-tolerated in patients (Klade et al., 2008). In Phase II clinical trials HLA-A2 positive patients with chronic hepatitis C received 6 doses of the vaccine with a 4-week interval between doses; although the content of circulating HCV RNA was not decreased, the increase in HCV specific CD8+ specific lymphocytes was observed in $25 \%$ of patients (Lauer et al., 2004). In the other study $66 \%$ of patients with chronic hepatitis $C$ (genotype 1) resistant to the standard therapy demonstrated a small but statistically significant decrease in HCV RNA observed 6 months after vaccination with IC41 (Klade et al., 2008).

Another CTL T-epitope-based vaccine was developed in Japan. It included a HLA-A2restricted HCV core protein-derived 35-44 fragment as CTL T-epitope injected in an emulsion with incomplete Freund's adjuvant during Phase I clinical trial. About 25\% patients (non-responders for the previous interferon plus ribavirin treatment) positively responded to vaccinations: alanine aminotransferase activity was lowered, and some patients showed the decline of viral load. However, all patients received more than 10 vaccinations, and some received even more than 50 injections of the peptide formulation (Yutani et al., 2009).

\subsubsection{Virosome-based peptide vaccine}

This vaccine developed by Pevion Biotech Ltd is under Phase I clinical trials. The virosome envelope consists of phospholipids with included influenza virus hemagglutinin and neuraminidase. The virosome contains a synthetic fragment of $\mathrm{HCV}$ core protein of 132 residues in length, which induced formation of virus specific cytotoxic T-cells producing [gamma]-interferon in HLA-A2.1 transgenic mice (Amacker et al., 2005). 


\subsection{Synthetic peptide vaccine against human papillloma virus, strain 16}

This vaccine has been developed in the Center for Genetic Engineering and Biotechnology, Havana, Cuba, and undergoes Phase II clinical trial now. It consists of HLA-A2-restricted human papilloma virus strain 16 (HPV16) E7 T-epitope incorporated into very small size proteoliposomes. Four vaccinations with this vaccine resulted in the clearance from HPV16 in 3 out of 7 immunized patients and in complete or at least partial regression of cervical lesions caused by HPV infection (Solares et al., 2011).

\subsection{Synthetic vaccine against foot-and-mouth disease}

Although inactivated vaccine against foot-and-mouth disease (FMD) may effectively protect animals it has some serious drawbacks such as: a) slow formation of the immune response and existing risk of viral infection of vaccinated animals before the development of the adaptive immune response; b) appearance of virus carriers even after successful vaccination; c) difficulties with discrimination of vaccinated animals from convalescence and infected animals (Barrett \& Stanberry, 2009).

During many years researchers try to develop alternative vaccines against FMD virus. Synthetic peptide vaccines based on the VP1 peptide fragments 135-160 and 200-213 containing virus neutralizing B-epitopes (Strohmaier et al., 1982) and the fragments of the same protein 20-41 and 170-189 containing T-helper epitopes (Collen et al., 1991; Volpina et al., 1993) are considered as possible variants. A synthetic vaccine based on the VP1 protein fragment 135-159 (FMD virus, strain 22) has been developed in M. M. Shemyakin and $\mathrm{Yu}$. A. Ovchinnikov Institute of Biooeganic Chemistry (Russian Academy of Sciences); this vaccine provided antiviral protection within one year after a single immunization (Volpina et al., 1993, 1999). It is the only synthetic peptide vaccine approved in Russia for the use in veterinary (Volpina et al., 1999).

\subsection{Dendrimeric peptide vaccine against swine fever virus}

Three dendrimeric peptide constructs were prepared from three different fragments of the classical swine fever virus (CSFV) envelope protein E2 (as B-epitopes) and T helper epitope from the NS3 protein of the same virus (Tarradas et al., 2011). Each dendrimer contained four copies of one of the putative B-epitopes linked to the T-epitope. Intramuscular injections with these dendrimers significally reduced the pig lethality after the challenge with the lethal dose of CSFV though no netralizing antibodies were detected in animal blood.

\section{Examples of peptide immunogens under current successful development}

\subsection{Peptide immunogens for universal anti-flu vaccines}

Current influenza vaccines protect mostly against homologous virus strains. However, while facing the danger of new pandemics expected from the transmittance of mutated bird and swine flu viruses to humans, the development of a broadly protective anti-flu vaccine is of great importance. Several groups succeeded in preparing conserved synthetic peptide immunogens derived from hemagglutinin and matrix M2 protein of the influenza virus. These fragments were shown to be conserved in various virus strains. Corresponding 
synthetic peptides conjugated with carrier protein keyhole limpet hemocyanin were able to elicit broadly specific immune response in mice and protect them from the influenza infection caused by different virus strains (Stanekova et al., 2011; Wang et al., 2010).

\subsection{Peptide immunogens for anti-HCV vaccines under development}

Antibodies protective against HCV infection should attack HCV envelope proteins, since these proteins are responsible for targeting the virus into the host cells, where its replication occurs (Gal-Tanamy et al., 2009; Voisset \& Dubuisson, 2004). However, HCV envelope proteins demonstrate the highest sequence variability, with regard to HCV genetic variants, among all viral proteins (Sobolev et al., 2000). Though the immunization with the full-size $\mathrm{HCV}$ envelope proteins can elicit virus-neutralizing antibodies, these antibodies are specific to certain HCV genetic variants, relative to the one, from which the envelope proteins used for immunization, are taken (Elmowalid et al., 2007; Alvarez-Lajonchere et al., 2009). Several highly conserved sites were determined in HCV envelope proteins E1 and E2 (Sobolev et al, 2000); however, most these sites did not elicit specific antibodies because of insufficient Tlymphocyte help resulting from the absence of T-helper epitopes in the vicinity. Conjugation of putative B-epitopes, derived from HCV envelope proteins, to promiscuous T-helper epitopes from other sources (Torresi et al., 2007) or to the carrier protein, keyhole limpet hemocyanin (El Awady et al., 2010; El Abd et al., 2011), resulted in the formation of immunogens capable of producing antibodies specific for the whole HCV envelope proteins and viral particles. However, the use of foreign T-epitopes and carrier proteins leads to the formation of $\mathrm{T}$ helper memory cells that are non-specific for $\mathrm{HCV}$ and hence, will not be activated upon HCV infection.

We performed a search for putative T-helper epitope motifs in HCV envelope proteins with the help of SYFPEITHI Database and detected several conserved fragments that contain a number of such motifs of different specificity with regard to HLA allele products. Hence these fragments can be considered as broadly specific $\mathrm{T}$ helper epitopes. Several artificial peptide constructs were made on the basis of one such E2 protein fragment (CR2; fragment designation here and in the table 1 in accordance with Sobolev et al., 2000) and three fragments from the same protein, shown to be responsible for the interaction of HCV with heparan-sulphates (Olenina et al., 2005). These artificial constructs were synthesized and tested for their immunogenicity on rats (table 1). The constructs were shown to be highly immunogenic in the absence of any carrier besides Freund's adjuvant and able to elicit antibodies that interacted with full-size envelope proteins. The mixture of all six constructs showed the comparable immunogenicity and enhanced ability in eliciting anti-E2 antibodies. Five out of six constructs as well as the mixture of constructs elicited antibodies capable of binding HCV from patient plasma(fig. 1) (Kolesanova et al., 2011).

\subsection{Other important examples of peptide immunogens}

An interesting example of the peptide immunogen has been developed for the candidate anti-anthrax vaccine. The current vaccines for anthrax though being efficient, require extensive immunization protocols, and one of the reasons for it is the absence of antibodies against the linear determinant in domain 2 of Bacillus anthracis protective antigen. Two multiple antigenic peptides composed of the fragment 304-319 (loop-neutralizing determinant) of $B$. anthracis protective antigen and a promiscuous T-helper epiope from $\mathrm{Pl}$. 


\begin{tabular}{|c|c|c|c|}
\hline \multirow{2}{*}{ Peptide } & Against peptide & $\begin{array}{c}\text { Against E2 } \\
\text { protein }\end{array}$ & $\begin{array}{c}\text { Against E1E2 } \\
\text { heterodimer }\end{array}$ \\
\cline { 2 - 4 } & $1: 32000$ & $1: 50-1: 100(3)$ & $1: 50-1: 100(3)$ \\
\hline $\begin{array}{c}\text { CR2-linker- } \\
\text { CR3 }\end{array}$ & $1: 8100$ & $1: 50-1: 100(3)$ & $1: 50-1: 100(3)$ \\
\hline $\begin{array}{c}\text { CR3-linker- } \\
\text { CR2 }\end{array}$ & $1: 900$ & $1: 50(1)$ & $1: 50(1)$ \\
\hline $\begin{array}{c}\text { PRR1-linker- } \\
\text { CR2 }\end{array}$ & $1: 9200$ & $1: 50(2)$ & $1: 50(2)$ \\
\hline $\begin{array}{c}\text { CR2-linker- } \\
\text { PRR1 }\end{array}$ & $1: 5600$ & $1: 50(2)$ & $1: 50(2)$ \\
\hline $\begin{array}{c}\text { CHR-linker- } \\
\text { CR2 }\end{array}$ & $1: 2700$ & $1: 50(1)$ & $1: 50(1)$ \\
\hline $\begin{array}{c}\text { CR2-linker } \\
\text { CHR }\end{array}$ & $1: 2000-1: 24000$ depending on \\
peptide & $1: 150(3)$ & $1: 100(3)$ \\
\hline Mixture of 6 & & \multicolumn{3}{|c|}{ Antibody titer* } \\
\hline
\end{tabular}

* Numbers in brackets show the number of animal antisera samples containing corresponding antibodies. Number of rats in experimental groups -5 ; the group immunized with mixture of the constructs consisted of 4 species.

Table 1. Artificial peptide constructs made from E2 HCV protein fragments and their immunogenicity testing results.

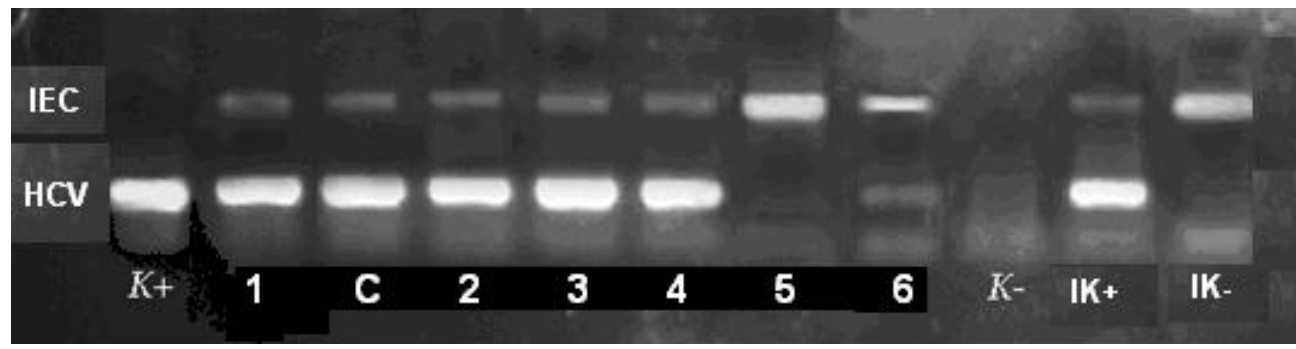

Fig. 1. HCV binding to antibodies elicited by artificial peptide constructs made from envelope protein E2 conserved fragments - PCR detection. Numbers in the line below designate the number of the construct used for the immunization (see table 1), C - mixture of all 6 constructs. $\mathrm{K}+$ and $\mathrm{K}-\mathrm{-}$ positive and negative control probes; IK+ and IK- - positive and negative internal controls; IEC - internal experiment control PCR product; $\mathrm{HCV}-\mathrm{HCV}$ derived PCR product.

falciparum were prepared with the B-T or T-B order of epitope determinants. Rabbits immunized with both constructs were efficiently protected from the lethal infection caused by aerosolized spores of B. anthracis. (Oscherwitz et al., 2010).

Peptide immunogens are also of interest as immunogens for anti-allergic vaccines. Since the aim of these vaccine preparation is to elicit antibodies that bind and clear off allergens from blood for preventing an allergic reaction, full-size allergen molecules can hardly be applied as immunogens. Allergen-derived epitope structures devoid of determinants responsible 
for causing allergic reactions are used instead. The development of the peptide immunotherapy peptide-based vaccine for cat allergy can be considered as one of such examples (Worm et al., 2011). Several peptides derived form the cat allergen Fel d1 that were identified as T-helper lymphocyte-stimulating molecules and synthesized, were safe and well tolerated in human volunteers. This vaccine was efficient in very small doses ( 3 nmols) and did not cause any allergic reactions that are caused by the full-size allergen molecule. Hence these peptide immunogens and the methodological basis for their development can be further used for the preparation of anti-allergic vaccines of other kinds.

\section{Conclusions}

Now there is a good background for the selection of immunogens targeted to those immune processes, which should be triggered by future vaccines. However, at the moment all known synthetic peptide vaccines against agents causing infectious diseases in man are at various stages of clinical trials (http://clinicaltrials.gov/ct2/results?term=vaccine). This situation is associated with the following circumstances: difficulties in reproduction of native conformation of protein antigenic sites, some B-cell epitopes recognized by neutralizing antibodies are discontinuous rather than linear ones; peptides are easily subjected to proteolysis. Peptides themselves are weakly immunogenic and such vaccine requires careful selection of an adjuvant. In the case of peptide vaccines salts and aluminum hydroxide, the adjuvants approved in all countries, are ineffective, whereas more effective adjuvants (for peptides) are not approved for clinical application in humans in most countries (e.g. they are forbidden for human use in the USA (Common Ingredients in U.S. Licensed Vaccines)). Nevertheless, deeper knowledge on structures of antigens of infectious agents, mechanisms of immune response formation, development of technologies for large-scale synthesis of long peptides, preparation of stabilized nanoparticles and the development of effective and safe adjuvants give hope that the effective peptide vaccines will be developed in the future.

\section{Acknowledgements}

The work on this chapter was supported with RFBR grant No. 09-04-12117 and the Federal program "Research and development on priority directions in scientific and technological complex of Russia in 2007-2012" contract No. 16.512.11.2069 (theme No. 2011-1.2-512-017031).

\section{References}

Abbas, A.K. \& Lichtman, A.H. (2011). Basic Immunology: Functions and Disorders of the Immune System. Saunders/Elsevier, ISBN 978-1-4160-5569-3, Philadelphia, PA, USA.

Aguilar, J.C. \& Rodriguez, E.G. (2007) Vaccine Adjuvants Revisited. Vaccine, Vol. 25, No.19 (May 10, 2007), pp. 3752-3762, ISSN 0264-410X.

Ahmed, R.K. \& Maeurer, M.J., (2009). T-Cell Epitope Mapping. In: Methods Mol. Biol., Vol. 524, No. 4. Epitope Mapping Protocols, M. Schutkowski \& Reineke, U. (Eds.), pp. 427438, Humana Press, ISBN 978-1-59745-450-6_32. 
Allison, A.C. \& Byars, N.E. (1991) Immunological Adjuvants: Desirable Properties and SideEffects. Mol. Immunol., Vol. 28, No.3 (March 1991), pp. 279-284, ISSN 0161-5890.

Alvarez-Lajonchere, L., Shoukry, N. H., Gra, B., Amador-Canizares, Y., Helle, F., Bedard, N., Guerra, I., Drouin, C., Dubuisson, J., Gonzalez-Horta, E. E., Martınez, G., Marante, J., Cinza, Z., Castellanos, M. \& Duenas-Carrera, S. (2009). Immunogenicity of CIGB230, a Therapeutic DNA Vaccine Preparation, in HCV-Chronically Infected Individuals in a Phase I Clinical Trial. J. Viral Hepat., 16, No. 2, (March 2009), pp.156-167, ISSN 1352-0504.

Amacker, M., Engler, O., Kammer, A.R., Vadrucci, S., Oberholzer, D., Cerny, A., \& Zurbriggen, R., (2005) Peptide-Loaded Chimeric Influenza Virosomes for Efficient In Vivo Induction of Cytotoxic T Cells. Int. Immunol., Vol. 17, No. 6, (June 2005), pp. 695-704, ISSN 0953-8178.

AMANET Launches Large-Scale Testing of Candidate Malaria Vaccine MSP3-LSP in Mali. Available at: http://www.amanet-trust.org/ext/reports/newsletters/issue23June08.pdf

Badell, E., Oeuvray, C., Moreno, A., Soe, S., van Rooijen, N., \& Bouzidi, A. (2000). Human Malaria in Immunocompromized Mice. An in Vivo Model to Study Defense Mechanisms against Plasmodium falciparum. J. Exp. Med., Vol. 192, No. 11, (December 4, 2000), pp. 1653-1660, ISSN 0022-1007.

Barocchi, M.A., Censini, S., \& Rappuoli, R. (2007) Vaccines in the Era of Genomics: the Pneumococcal Challenge. Vaccine, Vol. 25, No. 16 (April 20, 2007), pp. 2963-2973, ISSN: 0264-410X.

Barrett, A.D.T. \& Stanberry, L.R. (Eds.). (2009). Vaccines for Biodefense and Emerging and Neglected Diseases, Elsevier Inc., ISBN 978-0-3-69408-9.

Ben-Yedidia, T. and Arnon, R., (1997) Design of Peptide and Polypeptide Vaccines. Curr. Opin. Biotechnol., Vol. 8, No.4 (August, 1997), pp. 442-448, ISSN 0958-1669.

Bermúdes, A., Reyes, C., Guzmán, F., Vanegas, M., Rosas, J., Amador, R., Rodríguez, R., Patarroyo, M.A., \& Patarroyo, M.E. (2007). Synthetic Vaccine Update: Applying Lessons Learned from Recent SPf66 Malarial Vaccine Physicochemical, Structural and Immunological Characterization. Vaccine, Vol. 25, No. 22 (May 30, 2007), pp. 4487-4501, ISSN: 0264-410X.

Bijker, M.S., Melief, C.J., Offringa, R., and van der Burg, S.H., (2007) Design and Development of Synthetic Peptide Vaccines: Past, Present and Future. Expert Rev. Vaccines, Vol. 6, No.4 (August, 2007), pp. 591-603, ISSN 1476-0584.

Bongartz, J., Bruni, N., \& Or-Guil, M. (2009). Epitope Mapping Using Randomly Generated Peptide Libraries. In: Methods Mol. Biol., Vol. 524, No. 4. Epitope Mapping Protocols, M. Schutkowski \& Reineke, U. (Eds.), pp. 237-246, Humana Press, ISBN 978-159745-450-6_32.

Bouharoun-Tayoun, H., Oeuvray, C., Lunel, F., \& Druilhe, P. (1995). Mechanisms Underlying the Monocyte-Mediated Antibody-Dependent Killing of Plasmodium falciparum Asexual Blood Stages. J. Exp. Med., Vol. 182, No. 2, (August 1, 1995), pp. 409-418, ISSN 0022-1007. 
Bruckdorfer, T, Marder, O., \& Albericio, F. (2004). From Production of Peptides in Milligram Amounts for Research to Multi-tons Quantities for Drugs of the Future. Curr. Pharm. Biotechnol., Vol. 5, No. 1, (February 2004), pp. 29-43.

van der Burg, S.H., Bijker, M.S., Welters, M.J., Offringa, R., \& Melief, C.J. (2006) Improved Peptide Vaccine Strategies, Creating Synthetic Artificial Infections to Maximize Immune Efficacy. Adv. Drug. Deliv. Rev., Vol. 58, No.8, (October 1, 2006), pp. 916930, ISSN 0169-409X.

Castric, P.A. \& Cassels, F.J. (1997) Peptide Epitope Mapping in Vaccines. J. Ind. Microbiol. Biotechnol., Vol. 19, No.1 (July 1997), pp. 56-57.

Chua, B.Y., Eriksson, E.M., Brown, L.E., Zeng, W., Gowans, E.J., Torresi, J., \& Jackson, D.C. (2008). A Self-Adjuvanting Lipopeptide-Based Vaccine Candidate for the Treatment of Hepatitis C Virus Infection. Vaccine, Vol. 26, No.31, (September 2, 2008), pp. 4866-4875, ISSN 0264-410X.

Chua, B.Y., Zeng, W., Lau, Y.F., \& Jackson, D.C. (2007) Comparison of Lipopeptide-Based Immunocontraceptive Vaccines Containing Different Lipid Groups. Vaccine, Vol. 25, No. 1 (January 2, 2007), pp. 92-101, ISSN 0264-410X.

Collen, T., Dimarchi, D., \& Doel, T.R. (1991) A T Cell Epitope in VP1 of Foot-and-Mouth Disease Virus is Immunodominant for Vaccinated Cattle. J. Immunol., Vol. 146, No. 2 (January 15, 1991), pp. 749-755, ISSN 0022-1767.

Common Ingredients in U.S. Licensed Vaccines. (July, 2011). In: Vaccine Safety \& Availability, 7.07.2011, Available from http:/ / www.fda.gov/BiologicsBloodVaccines/SafetyAvailability/VaccineSafety/ ucm187810.htm.

Cox, E., Verdonck, F., Vanrompay, D., \& Goddeeris, B. (2006). Adjuvants Modulating Mucosal Immune Responses or Directing Systemic Responses towards the Mucosa. Vet. Res., Vol. 37, No. 3, (May-June 2006), pp. 511-539, ISSN 0928-4249.

Deliyannis, G., Kedzierska, K., Lau, Y.F., Zeng, W., Turner, S.J., \& Jackson, D.C. (2006) Intranasal Lipopeptide Primes Lung-Resident Memory CD8+ T Cells for LongTerm Pulmonary Protection against Influenza. Eur. J. Immunol., Vol. 36, No. 3 (March, 2006), pp. 770-778, ISSN 0014-2980.

Dodoo, D., Theisen, M., Kurtzhals, J.A., Akanmori, B.D., Koram, K.A., Jepsen, S., Nkrumah, F.K., Theander, T.G. \& Hviid, L. (2000). Naturally Acquired Antibodies to the Glutamate-Rich Protein are Associated with Protection against Plasmodium falciparum Malaria. J. Infect. Dis.,@ 2000, vol. 181, pp. 1202-1205, ISSN 0022-1899.

Druilhe, P., Spertini, F., Soesoe, D., Corradin, G., Mejia, P., Singh, S., Audran, R., Bouzidi, A., Oeuvray, C., \& Roussilhon, C. (2005). A Malaria Vaccine that Elicits in Humans Antibodies Able to Kill Plasmodium falciparum. PLoS Med., Vol. 2, No. 11, e344 . Available at

http://www.plosmedicine.org/article/info\%3Adoi\%2F10.1371\%2Fjournal.pmed.0 020344 .

Düesberg, U., von dem Bussche, A., Kirschning, C., Miyake, K., Sauerbruch, T., \& Spengler, U. (2002). Cell Activation by Synthetic Lipopeptides of the Hepatitis C Virus (HCV)-Core Protein Is Mediated by Toll Like Receptors (TLRs). Immunol. Lett., Vol. 84, No.2 (December 1, 2002), pp. 89-95, ISSN 0165-2478. 
El Abd, Y.S., Tabll, A.A., Bader El Din, N.G., Hosny, A.E., Moustafa, R.I., El-Shenawy, R., Atef, K. \& El-Awady, M.K. (2011). Neutralizing Activities of Caprine Antibodies towards Conserved Regions of the HCV Envelope Glycoprotein E2. Virol. J., Vol. 8, No. 1, (August 5, 2011), p.391, ISSN 1743-422X.

El-Awady, M.K., Tabll, A.A., Yousif, H., El-Abd, Y., Reda, M., Khalil, S.B., El-Zayadi, A.R., Shaker, M.H. \& Bader El Din, N.G. (2010). Murine Neutralizing Antibody Response and Toxicity to Synthetic Peptides Derived from E1 and E2 Proteins of Hepatitis C Virus. Vacc ine, Vol. 28, No. 52 (December, 6, 2010), pp. 8338-8344, ISSN 0264-410X.

Eldridge, J.H., Staas, J.K., Meulbroek, J.A., Tice, T.R., \& Gilley, R.M. (1991). Biodegradable and Biocompatible Poly(DL-Lactide-co-Glycolide) Aicrospheres as an Adjuvant for Staphylococcal Enterotoxin B Toxoid which Enhances the Level of ToxinNeutralizing Antibodies. Infect. Immun., Vol. 59, No. 9, (September 1991), pp. 29782983, ISSN 0019-9567.

Elmowalid, G.A., Qiao, M., Jeong, S.H., Borg, B.B., Baumert, T.F., Sapp, R.K., Hu, Z., Murthy, K., Liang, T.J. (2007). Immunization with Hepatitis C Virus-Like Particles Results in Control of Hepatitis C Virus Infection in Chimpanzees. Proc. Natl. Acad. Sci. USA, Vol. 104, No. 20, (May 15, 2007), pp.8427-8432, ISSN 0027-8424.

Engler, O.B., Schwendener, R.A., Dai, W.J., W@lk, B., Pichler, W., Moradpour, D., Brunner, T., \& Cerny, A. (2004). A Liposomal Peptide Vaccine Inducing CD8+ Cells in HLAA2.1 Transgenic Mice, which Recognise Human Cells Encoding hepatitis C Virus (HCV) Proteins. Vaccine, Vol. 23, No. 1, (November 15, 2004), pp. 58-68, ISSN 0264410X.

Epstein, J.E., Giersing, B., Mullen, G., Moorthy, V., \& Richie, T.L.,(2007) Malaria Vaccines: Are We Getting Closer? Curr. Opin. Mol. Ther., Vol. 9, No. 1, (February 2007), pp. 12-24, ISSN 1464-8431.

Firbas, C., Jilma, B., Tauber, E., Buerger, V., Jelovcan, S., \& Lingnau, K., Buschle, M., Frisch, J., Klade, C.S. (2006) Immunogenicity and Safety of a Novel Therapeutic Hepatitis C Virus (HCV) Peptide Vaccine: a Randomized, Placebo Controlled Trial for Dose Optimization in 128 Healthy Subjects. Vaccine, Vol. 24, No. 20, (May 15, 2006), pp. 4343-4353, ISSN 0264-410X.

Felgner, P.L., Kayala, M.A., Vigil, A., Burk, C., Nakajima-Sasaki, R., Pablo, J., Molina, D.M., Hirst, S., Chew ,J.S.W., Wang, D., Tan, G., Duffield, M., Yang, R., Neel, J., Chantratita, N., Bancroft, G., Lertmemongkolchai, G., Davies, D.H., Baldi, P., Peacock, S., \& Titball, R.W. (2009) A Burkholderia pseudomallei Protein Microarray Reveals Serodiagnostic and Cross-Reactive Antigens. Proc. Natl. Acad. Sci. USA, Vol. 106, No.32, (August 11, 2009), pp. 13499-13504, ISSN 0027-8424.

Freeman, A.J., Pan, Y., Harvey, C.E., Post, J.J., Law, M.G., White, P.A., Rawlinson, W.D., Lloyd, A.R., Marinos, G. \& French, R.A. (2003). The Presence of an Intrahepatic Cytotoxic T Lymphocyte Response is Associated with Low Viral Load in Patients with Chronic Hepatitis C Virus Infection.J. Hepatol., Vol. 38, No. 3, (March 2003), pp.349-356, ISSN 0168-8278.

Fritzer, A., Senn, B.M., Minh, D.B., Hanner, M., Gelbmann, D., Noiges, B., Henics, T., Schulze, K., Guzman, C.A., Goodacre, J., von Gabain, A., Nagy, E. \& Meinke, A.L. (2010) Novel Conserved Group A Streptococcal Proteins Identified by the 
Antigenome Technology as Vaccine Candidates for a non-M Protein-Based Vaccine. Infect Immun., Vol.78, No.9, (September, 2010), pp. 4051-4067, ISSN 10985522.

Gal-Tanamy M., Walker C., Foung S., Lemon S.M. (2009). Hepatitis C. In: Vaccines for Biodefence and Emerging and Neglected Diseases, A.T. Barrett and L.R. Stanberry (Eds.). Academic Press, London-Amsterdam-Burlington-San Diego, pp. 413-440, ISBN 978-0-3-69408-9.

Garg, A.D, Nowis, D., Golab, J., Vandenabeele, P., Krysko, D.V., \& Agostinis, P. (2010) Immunogenic cell death, DAMPs and anticancer therapeutics: an emerging amalgamation. Biochim Biophys Acta, Vol.1805, No.1 (January, 2010), pp.53-71, ISSN 0304-419X.

Glowalla, E., Tosetti, B., Krönke, M., \& Krut, O. (2009) Proteomics-Based Identification of Anchorless Cell Wall Proteins as Vaccine Candidates against Staphyllococcus aureus. Infect. Immun., Vol. 77, No. 7, (July, 2009), pp. 2719-2729, ISSN 1098-5522.

Graves, P. \& Gelband, H. (2007). Vaccines for Preventing Malaria. Cochrane Database Sys. Rev., No. 4, July 18, 2007. Available at http:// onlinelibrary.wiley.com/doi/10.1002/14651858.CD000129.pub2/pdf.

Guévin, C., Lamarre, A., \& Labonté, P. (2009). Novel HCV Replication Mouse Model Using Human Hepatocellular Carcinoma Xenografts.Antiviral Res., Vol. 84, No. 1, (October 2009), @ 2009, pp. 14-22, ISSN 0166-3542.

Haro, I., Pérez, S., García, M., Chan, W.C., Ercilla, G. (2003). Liposome Entrapment and Immunogenic Studies of a Synthetic Lipophilic Multiple Antigenic Peptide Bearing VP1 and VP3 Domains of the Hepatitis A Virus: a Robust Method for Vaccine Design. FEBS Lett., Vol. 540, No. 1-3, (April 10, 2003), pp. 133-140, ISSN .

He, Y., Rappuoli, R., De Groot, A.S. \& Chen, R.T. (2010). Emerging Vaccine Informatics. J. Biomed. Biotechnol., 2010; 2010: 218590 (June 15, 2011), ISSN 1110-7251.

Jackson, D.C., Lau, Y.F., Le, T., Suhrbier, A., Deliyannis, G., \& Cheers, C. (2004). A Totally Synthetic Vaccine of Generic Structure that Targets Toll-Like Receptor 2 on Dendritic Cells and Promotes Antibody or Cytotoxic T Cell Responses. Proc. Natl. Acad. Sci. USA, Vol. 101, No. 43 (October 26, 2004), pp. 15440-15445, ISSN 00278424.

Jackson, D.C., Purcell, A.W., Fitzmaurice, C.J., Zeng, W., \& Hart, D.N. (2002) The Central Role Played by Peptides in the Immune Response and the Design of Peptide-Based Vaccines against Infectious Diseases and Cancer. Curr. Drug Targets, Vol. 3, No.2, (April 2002), pp. 175-196, ISSN 1389-4501.

Kalyuzhny, A.E., (Ed.). (2005) Handbook of ELISPOT. Methods and Protocols, Humana Press, ISBN 978-1-58829-469-2.

Kaplun, A.P., Le Bang Shon, Krasnopolskii, Yu.M., \& Shvets, V.I. (1999). Liposomes and Other Nanoparticles as Drug Delivery Means. Vopr. Med. Khim., Vol. 45, No. 1, pp. 3-12, ISSN 0042-8809.

Khaitov, R.M. \& Pinegin, B.V. (2005). Modern Views on the Polyoxidonium Mechanism of Action. Immunologiya, No. 4, (April 2005), pp. 197-205.

Kensil, C.R. (1996). Saponins as Vaccine Adjuvants. Crit. Rev. Ther. Drug. Carrier. Syst., Vol. 13, No. 1-2, pp. 1-55, ISSN 0743-4863. 
Klade, C.S. (2002) Proteomics Approaches towards Antigen Discovery and Vaccine Development. Curr. Opin. Mol. Ther., Vol. 4, No. 3, (June, 2002), pp. 216-223, ISSN 1464-8431.

Klade, C.S., Wedemeyer, H., Berg, T., Hinrichsen, H., Cholewinska, G., Zeuzem, S., Blum, H., Buschle, M., Jelovcan, .S, Buerger, V., Tauber, E., Frisch, J., Manns, M.P. (2008) Therapeutic Vaccination of Chronic Hepatitis C Nonresponder Patients with the Peptide Vaccine IC41. Gastroenterology, Vol. 134, No. 5, (May 2008), pp. 1385-1395, ISSN 0016-5085.

Kolesanova, E.F., Farafonova, T.E., Moisa, A.A., Aleshina, E.Yu., Pyndyk, N.V., Sobolev, B.N. \& Archakov, A.I. (2011). Development of Peptide Immunogens for Anti-HCV Vaccine. In: Peptide Science 2010, N. Fujii \& Y. Kiso (Eds.), p.33, The Japanese Peptide Society, Osaka, ISBN 978-4-931541-11-5.

Kupriianova, M.A., Zhmak, M.N., Koroev, D.O., Chepurkin, A.V., Volpina, O.M., \& Ivanov, V.T. (2000). Synthetic Peptide Designs Based on Immunoactive Fragments of the VP1 Protein of the Foot-and-Mouth Disease Virus Strain A22. Bioorgan. Khim. (Russ.), Vol. 26, No.12 (December 2000), pp. 926-933.

Kuzmina, T.I., Olenina L.V., Sanzhakov, M.A., Farafonova, T.E., Abramikhina, T.V., Dubuisson, J., Sobolev, B.N., \& Kolesanova, E.F. (2009). Antigenicity and B-Epitope Mapping of hepatitis C Virus Envelope Protein E2. Biochemistry (Moscow) Supplement Series B: Biomedical Chemistry, Vol. 3, No. 2, pp. 177-182, ISSN 1990-7508.

Lauer, G.M., Barnes, E., Lucas, M., Timm, J., Ouchi, K., Kim, A.Y., Day, C.L., Robbins, G.K., Casson, D.R., Reiser, M., Dusheiko, G., Allen, T.M., Chung, R.T., Walker, B.D., \& Klenerman, P., (2004). High Resolution Analysis of Cellular Immune Responses in Resolved and Persistent Hepatitis C Virus Infection. Gastroenterology, Vol. 27, No. 3 (September, 2004), pp. 924-936, ISSN 0016-5085.

Law, M., Maruyama, T., Lewis, J., Giang, E., Tarr, A.W., Stamataki, Z., Gastaminza, P., Chisari, F.V., Jones, I.M., Fox, R.I., Ball, J.K., McKeating, J.A., Knellerman, N.M. \& Burton, D.R. (2008). Broadly Neutralizing Antibodies Protect against Hepatitis C Virus Quasispecies Challenge. Nat Med., Vol. 14, No. 1, (January 14, 2008), pp. 2527, ISSN 1078-8956.

Liljeqvist, S. \& Stahl, S.J. (1999).Recombinant Subunit Vaccines: Protein Immunogens, Live Delivery Systems or Nucleic Acid Vaccines. J. Biotechnol., Vol.73, No.1, pp.1-33, ISSN 0168-1656.

Lin, H.H., Zhang, G.L., Tongchusak, S., Reinherz, E.L., \& Brusic, V. (2008) Evaluation of MHC-II Peptide Binding Prediction Servers: Applications for Vaccine Research. BMC Immunol., Vol. 9, No.8, (March 16, 2008), ISSN 1471-2172. Available at: http://www.biomedcentral.com/1471-2172/9/8.

Ling, E., Feldman, G., Portnoi, M., Dagan, R., Overweg, K., Mulholland, F., Chalifa-Caspi, V., Wells, J., \& Mizrachi-Nebenzahl, Y. (2004). Glycolytic Enzymes Associated with the Cell Surface of Streptococcus pneumoniae are Antigenic in Humans and Elicit Protective Immune Responses in the Mouse. Clin. Exp. Immunol., Vol. 138, No. 2, (November, 2004), pp. 290-298, ISSN 0009-9104.

Lloyd-Williams, P., Albericio, F., \& Giralt, E. (1997). Chemical Approaches to the Synthesis of Peptides and Proteins, CRC Press LLC, New York, ISBN 978-0-84939-142-2. 
Lu, X., DeFelippis, M.R., \& Huang, L. (2009). Linear Epitope Mapping by Native Mass Spectrometry. Anal. Biochem., Vol. 395, No.1 (December 1, 2009), pp. 100-107, ISSN 0003-2697.

Machiels, J.P., van Baren, N., and Marchand, M.(2002). Peptide-Based Cancer Vaccines. Semin Oncol., Vol. 29, No.5 (October, 2002), pp. 494-502, ISSN 0093-7754.

MacNamara, A., Kadolsky, U., Bangham, C.R., \& Asquith, B. (2009). T-cell Epitope Prediction: Rescaling Can Mask Biological Variation between MHC Molecules. PLoS Comput. Biol., Vol. 5, No. 3, (March 2009), e1000327, eISSN 1553-7358.

Mäkelä, P.H. (2000) Vaccines, Coming of Age after 200 Years. FEMS Microbiol. Rev., Vol. 24, No. 1 (January, 2000), pp. 9-20, ISSN 0168-6445.

Male, D., Brostoff, J., Roth, D. \& Roitt, I. (2006). Immunology 7th Edition, MOSBY Elsevier, ISBN 978-0-323-05448-5.

Målen, H., Søfterland, T., \& Wiker, H.G. (2008). Antigen Analysis of Mycobacterium tuberculosis H37Rv Culture Filtrate Proteins. Scand. J. Immunol., Vol. 67, No. 3, (March, 2008), pp. 245-252, ISSN 0300-9475.

Meinke, A., Henics, T., Hanner, M., Minh, D.B., \& Nagy, E. (2005) Antigenome Technology: a Novel Approach for the Selection of Bacterial Vaccine Candidate Antigens. Vaccine, Vol. 23, No. 17-18, (March 18, 2005), pp. 2035-2041, ISSN: 0264-410X.

Mitsuaki, N., Shizuko, I., Satoshi, N., \& Takuya, I. (1987). Peptide Synthesis by Fragment Condensation on a Soluble Polymer Support. 8. Maximum Peptide Chain Lengths of Carboxyl Component Peptides for Effective Coupling Reactions with Amino Component Peptides Anchored to Soluble and Cross-Linked Polystyrene Supports. Macromolecules, vol. 20, No.9, (September 1987), pp. 2306-2307, ISSN 0024-9297.

Moss, C.X., Tree, T.I., \& Watts, C. (2007). Reconstruction of a Pathway of Antigen Processing and Class II MHC Peptide Capture. EMBO J., Vol. 26, No.8, (April 18, 2007), pp. 2137-2147, ISSN 0261-4189.

Muhlradt, P.F., Kiess, M., Meyer, H., Sussmuth, R., \& Jung, G.J. (1997) Isolation, Structure Elucidation, and Synthesis of a Macrophage Stimulatory Lipopeptide from Mycoplasma fermentans Acting at Picomolar Concentration. J. Exp. Med., Vol. 185, No. 11, (June 2, 1997), pp. 1951-1958, ISSN 0022-1007.

Müller, M.R., Wiesmüller, K.H., Jung, G., Loop, T., Humar, M., Pfannes, S.D., Bessler, W.G., Mittenbühler, K. (2002). Lipopeptide Adjuvants: Monitoring and Comparison of P3CSK4- and LPS-induced Gene Transcription. Int. Immunopharmacol., Vol. 2, No.8, (July 2002), pp. 1065-1077, ISSN 1567-5769.

Okitsu, S.L., Kienzl, U., Moehle, K., Silvie, O., Peduzzi, E., Mueller, M.S., Sauerwein, R.W., Matile, H., Zurbriggen, R., Mazier, D., Robinson, J.A., \& Pluschke, G. (2007) Structure-Activity-Based Design of a Synthetic Malaria Peptide Eliciting Sporozoite Inhibitory Antibodies in a Virosomal Formulation. Chem. Biol., Vol. 14, No. 5 (May 2007), pp. 577-587, ISSN 1074-5521.

Olenina, L.V., Nikolaeva, L.I., Sobolev, B.N., Blokhina, N.P., Archakov, A.I., \& Kolesanova, E.F. (2002) Mapping and Characterization of B Cell Linear Epitopes in the Conservative Regions of Hepatitis C Virus Envelope Glycoproteins. J. Viral Hepat., Vol. 9, No.3, (May 2002), pp. 174-182, ISSN 1352-0504. 
Olenina, L.V., Kuzmina, T.I., Kuraeva, T.E., Sobolev, B.N., Kolesanova, E.F. \& Archakov, A.I. (2003). Development of Laboratory Experimental Samples of Artificial Vaccine against Hepatitis C Virus. Immunogenicity of Highly Conserved Envelope Protein E2 Sites in Synthetic Constructs. Novosti nauki i tehniki. Ser. Meditsina. Allergiya, astma $i$ klinicheskaya immunologiya, No. 9, pp. 51-53.

Olenina, L.V., Kuzmina, T.I., Sobolev, B.N., Kuraeva, T.E., Kolesanova, E.F. \& Archakov, A.I. (2005). Identification of Glycosaminoglycan-Binding Sites within Hepatitis C Virus Envelope Glycoprotein E2. J. Viral Hepat., Vol. 12, No. 6, (Novemder 2005), pp. 584593, ISSN 1352-0504.

Palena, C., Abrams, S.I., Schlom, J., \& Hodge, J.W. (2006). Cancer Vaccines: Preclinical Studies and Novel Strategies. Adv. Cancer. Res., Vol. 95, pp. 115-145, ISSN 0065230X.

Panina-Bordignon, P., Tan, A., Termijtelen, A., Demotz, S., Corradin, G., \& Lanzavecchia, A.(1989). Universally Immunogenic T Cell Epitopes: Promiscuous Binding to Human MHC Class II and Promiscuous Recognition by T Cells. Eur. J. Immunol., Vol. 19, No.12 (December 1989), pp. 2237-2242, ISSN 0014-2980.

Pereboeva, L.A., Pereboev, A.V., Wang, L.F., \& Morris, G.E. (2000). Hepatitis C Epitopes from Phage-Displayed cDNA Libraries and Improved Diagnosis with a Chimeric Antigen. J. Med. Virol., Vol. 60, No. 2 (February 2000), pp. 144-151, ISSN 0146-6615.

Perry, L.C., Jones, T.D., \& Baker, M.P. (2008) New Approaches to Prediction of Immune Responses to Therapeutic Proteins during Preclinical Development. Drugs R. D., Vol. 9, No.6, pp. 385-396, ISSN 1174-5886.

Rappuoli, R. (2001). Reverse vaccinology, a genome-based approach to vaccine development. Vaccine, Vol. 19, No. 17-19 (March 21), pp. 2688-2691, ISSN 0264$410 X$.

Rinnová, M., Lebl, M., Souček, M. (1999). Solid-Phase Peptide Synthesis by Fragment Condensation: Coupling in Swelling Volume. Lett. Peptide Sci., Vol. 6, No. 1, (pp. 1522, ISSN 0929-5666.

Rodriguez, L.L., Barrera, J., Kramer, E., Lubroth, J., Brown, F., \& Golde, W.T. (2003). A Synthetic Peptide Containing the Consensus Sequence of the G-H Loop Region of Foot-and-Mouth Disease Virus Type-O VP1 and a Promiscuous T-helper Epitope Induces Peptide-specific Antibodies but Fails to Protect Cattle against Viral Challenge. Vaccine, Vol. 21, No. 25-26, (September 8, 2003), pp. 3751-3756, ISSN: 0264-410X.

Roestenberg, M., Remarque, E., de Jonge, E., Hermsen, R., Blythman, H., Leroy, O., Imoukhuede, E., Jepsen, S., Ofori-Anyinam, O., Faber, B., Kocken, C.H., Arnold, M., Walraven, V., Teelen, K., Roeffen, W., de Mast, Q., Ballou, W.R., Cohen, J., Dubois, M.C., Ascarateil, S., van der Ven, A., Thomas, A., \& Sauerwein R. (2008). Safety and Immunogenicity of a Recombinant Plasmodium falciparum AMA1 Malaria Vaccine Adjuvanted with Alhydrogel ${ }^{\mathrm{TM}}$, Montanide ISA 720 or AS02. PLoS One, Vol. 3, No.12, (December 18, 2008), e3960,pp. 1-12, eISSN-1932-6203.

Roggen, E.L. (2006). Recent Developments with B-cell Epitope Identification for Predictive Studies. J. Immunotoxicol., Vol. 3, No.3 (September 1, 2006), pp. 137-149, ISSN 15476901. 
Sabatino, G. \& Papini, A.M. (2008). Advances in Automatic, Manual and MicrowaveAssisted Solid-Phase Peptide Synthesis. Curr. Opin. Drug. Discov. Devel., Vol. 11, No.6, (November 2008), pp. 762-770, ISSN 1367-6733.

Scheerlinck, J.P. \& Greenwood, D.L. (2008). Virus-Sized Vaccine Delivery Systems. Drug. Discov. Today, 2008, Vol. 13, No. 19-20, (October 2008), pp. 882-887, ISSN 1359-6446.

Scheerlinck, J.P. \& Greenwood, D.L. (2006). Particulate Delivery Systems for Animal Vaccines. Methods, 2006, Vol. 40, No. 1, pp. 118-124, ISSN 1046-2023.

Schlaphoff, V., Klade, C.S., Jilma, B., Jelovcan, S.B., Cornberg, M., Tauber, E., Manns, M.P., \& Wedemeyer, H. (2007). Functional and Phenotypic Characterization of PeptideVaccine-Induced HCV-Specific CD8+ T Cells in Healthy Individuals and Chronic Hepatitis C Patients. Vaccine, Vol. 25, No.37-38, (September 17, 2007), pp. 6793-6806, ISSN 0264-410X.

Schuler, M.M., Nastke, M.D. \& Stevanovic, S. (2007) SYFPEITHI: Database for Searching and T-cell Epitope Prediction. In: Methods Mol. Biol. Vol. 409, No.1. Immunoinformatics. Predicting Immunogenicity In Silico, pp. 75-93, Flower, D.R. (Ed.), Springer, ISBN 978-1-60327-118-9.

Sesardic, D. J. (1993) Synthetic peptide vaccines. J. Med. Microbiol., Vol. 39, pp. 241-242, ISSN 0022-2615.

Sieker, F., May, A., \& Zacharias, M. (2009). Predicting Affinity and Specificity of Antigenic Peptide Binding to Major Histocompatibility Class I Molecules. Curr. Protein. Pept. Sci., Vol. 10, No. 3, (March 2009), pp. 286-296, ISSN 1389-2037.

Singh, M., Kazzaz, J., Ugozzoli, M., Malyala, P., Chesko, J., \& O'Hagan, D.T. (2006), Polylactide-co-Glycolide Microparticles with Surface Adsorbed Antigens as Vaccine Delivery Systems. Curr. Drug. Deliv., vol. 3, No.1 (January 2006), pp. 115120, ISSN 1567-2018.

Sirima, S.B., Tiono, A.B., Ouédraogo, A., Diarra, A., Ouédraogo, A.L., Yaro, J.B., Ouédraogo, E., Gansané, A., Bougouma, E.C., Konaté, A.T., Kaboré, Y., Traoré, A., Roma, C., Soulama, I., Luty, A.J., Cousens, S., \& Nébié, I. (2009). Safety and Immunogenicity of the Malaria Vaccine Candidate MSP3 Long Synthetic Peptide in 12-24 Monthsold Burkinabe Children. PLoS One, Vol. 4, No.10,e7549. Available at http://www.plosone.org/article/info\%3Adoi\%2F10.1371\%2Fjournal.pone.0007549.

Sobolev, B.N., Olenina, L.V., Kolesanova, E.F., Poroikov, V.V., \& Archakov, A.I. (2005) Computer Design of Vaccines: Approaches, Software Tools and Informational Resources. Curr. Computer-Aided Drug Design, Vol. 1, No.2, pp. 207-222, ISSN: 15734099.

Sobolev, B.N., Poroikov, V.V., Olenina, L.V., Kolesanova, E.F. \& Archakov, A.I. (2000). Comparative Analysis of Amino Acid Sequences from Envelope Proteins Isolated from Different Hepatitis C Virus Variants: Possible Role of conservative and variable regions. J. Viral Hepat., Vol.7, No. 4, (September 2000), pp. 368-374, ISSN 1352-0504.

Sobolev, B.N., Poroikov, V.V., Olenina, L.V., Kolesanova, E.F., \& Archakov, A.I. (2003). Computer-Assiated Vaccine Design. Biomed.Khim. (Russ)., 2003, Vol. 49, No. 4, (July-August 2003), pp. 309-332. 
Soe, S., Theisen, M., Roussilhon, C., Aye, K.S., \& Druilhe, P. (2004). Association between Protection against Clinical Malaria and Antibodies to Merozoite Surface Antigens in an Area of Hyperendemicity in Myanmar: Complementarity between Responses to Merozoite Surface Protein 3 and the 220-Kilodalton Glutamate-Rich Protein. Infect. Immun., vol. 72, No. 1, (January 2004), pp. 247-252, ISSN 0019-9567.

Solares, A.M., Baladron, I., Ramos T., Valenzuela, C., Borbon, Z., Fanjull, S., Gonzalez, L., Castillo, D., Esmir, J., Granadillo, M., Batte, A., Cintado, A., Ale, M., de Cossio, M.E.F., Ferrer, A., Torrens, I., Lopez-Saura, P. (2011). Safety and Immunogenicity of a Human Papillomavirus Peptide Vaccine (CIGB-228) in Women with High-Grade Cervical Intraepithelial Neoplasia: First-in-Human, Proof-of-Concept Trial. ISRN Obstetrics and Gynecology, Vol.2011, Article ID292951, 9 pp.

Stanekova, Z., Király, J., Stropkovská. A., Mikušková. T., Mucha. V., Kostolanský. F. \& Varečková, E. (2011). Heterosubtypic Protective Immunity against Influenza A Virus Induced by Fusion Peptide of the Hemagglutinin in Comparison to Ectodomain of M2 Protein. Acta Virol., Vol.55, No. 1, pp. 61-67, ISSN 0001-723X.

Strohmaier, K., Franze, R., \& Adam, K.H. (1982) Location and Characterization of the Antigenic Portion of the FMDV Immunizing Protein. J. Gen. Virol., Vol. 59, Pt.2, (April 1982), pp. 295-306.

Svirshchevskaya, E.V., Alekseeva, L.G., Reshetov, P.D., Phomicheva, N.N., Parphenyuk, S.A., Ilyina, A.V., Zueva, V.S., Lopatin, S.A., Levov, A.N. \& Varlamov, V.P. (2009). Mucoadjuvant properties of lipo- and glycoconjugated derivatives of oligochitosans. Eur. J. Med. Chem., Vol.44, No.5, pp.2030-2037.

Takahashi, H., Takeshita, T., Morein, B., Putney, S., Germain, R.N., \& Berzofsky, J.A. (1990). Induction of CD8+ Cytotoxic Cells by Immunization with Purified HIV-1 Envelope Protein in ISCOMs. Nature, Vol. 344, No. 6269 (April 26, 1990), pp. 873-875, ISSN 0028-0836.

Takala, S.L. \& Plowe, C.V. (2009). Genetic Diversity and Malaria Vaccine Design, Testing and Efficacy: Preventing and Overcoming 'Vaccine Resistant Malaria'. Parasite Immunol., Vol. 31, No. 9, (September 2009), pp. 560-573, ISSN 0141-9838.

Tam, J.P. (1988). Synthetic Peptide Vaccine Design: Synthesis and Properties of a HighDensity Multiple Antigenic Peptide System. Proc. Natl. Acad. USA, Vol. 85, No.15, (August 1988), pp. 5409-5413, ISSN 0027-8424.

Tarradas, J., Monso, M., Muños, M., Rosell, R., Fraile, L., Frias, M.T., Domingo, M., Andreu, D., Sobrino, F. \& Ganges, L. (2011). Partial Protection against Classical Swine Fever Virus Elicited by Dendrimeric Vaccine Candidate Peptides in Domestic Pigs. Vaccine, Vol 29, No. 26, (June10, 2011), pp.4422-4429, ISSN 0264-410X.

Tedeschi, G., Taverna, F., Negri, A., Piccinini, R., Nonnis, S., Ronchi, S., \& Zecconi, A. (2009) Serological Proteome Analysis of Staphylococcus aureus Isolated from Sub-clinical Mastitis. Vet. Microbiol., Vol. 134, No. 3-4, (March 2, 2009), pp. 388-391, 0378-1135.

Tester, I., Smyk-Pearson, S., Wang, P., Wertheimer, A., Yao, E., Lewinsohn, D.M., Tavis, J.E., \& Rosen, H.R. (2005) Immune Evasion versus Recovery after Acute Hepatitis C Virus Infection from a Shared Source. J. Exp Med, Vol. 201, No. 11 (June 6, 2005), pp. 1725-1731, ISSN 0022-1007. 
The Methodical Recommendations 1/4.2.588-96,(1998). Information-Editorial Center, Ministry of Public Health, Moscow, Russia.

The Sanitary Rules 3.3.2.015-94 (1995). Approved by State Sanitary and Epidemiologic Inspection, on 12.08.94, Ministry of Public Health of Russian Federation, Moscow, Russia.

The Sanitary Rules 3.3.2.561-96, approved by State Sanitary and Epidemiologic Inspection, on 31.10.96, Moscow: Information-Editorial Center, Ministry of Public Health, 1998.

Theisen, M., Dodoo, D., Toure-Balde, A., Soe, S., Corradin, G., Koram, K.K., Kurtzhals, J.A., Hviid, L., Theander, T., Akanmori, B., Ndiaye, M. \& Druilhe, P.(2001) Selection of Glutamate-Rich Protein Long Synthetic Peptides for Vaccine Development: Antigenicity and Relationship with Clinical Protection and Immunogenicity. Infect. Immun., Vol. 69, No. 9, (September 2001), pp. 11-17, ISSN 0019-9567.

Theisen, M., Soe, S., Jessing, S.G., Okkels, L.M., Danielsen, S., Oeuvray, C., Druilhe, P. \& Jepsen, S. (2000) Identification of a Major B-Cell Epitope of the Plasmodium falciparum Glutamate-Rich Protein (GLURP), Targeted by Human Antibodies Mediating Parasite Killing. Vaccine, Vol. 19, No. 2-3 (September 15, 2000), pp.204212, ISSN 0264-410X.

Thompson, F.M., Porter, D.W., Okitsu, S.L., Westerfeld, N., Vogel, D., Todryk, S., Poulton, I., Correa, S., Hutchings, C., Berthoud, T., Dunachie, S., Andrews, L., Williams, J.L., Sinden, R., Gilbert, S.C., Pluschke, G., Zurbriggen, R., Hill, A.V. Evidence of Blood Stage Efficacy with a Virosomal Malaria Vaccine in a Phase IIa Clinical Trial. PLoS One,Vol. 3 No. 1 (January 30, 2008). Available at http:/ / www.plosone.org/article/info\%3Adoi\%2F10.1371\%2Fjournal.pone.0001493

Tian, F., Yang, L., Lv, F., Yang, Q., \& Zhou, P. (2009). In silico Quantitative Prediction of Peptides Binding Affinity to Human MHC Molecule: an Intuitive Quantitative Structure-Activity Relationship Approach. Amino Acids, Vol. 36, No.3, (March 2009), pp. 535-354, ISSN 1438-2199.

Torresi, J., Stock, O.M., Fischer, A.E., Grollo, L., Drummer, H., Boo, I., Zeng, W., EarnestSilveira, L., \& Jackson, D.C. (2007). A Self-Adjuvanting Multiepitope Immunogen that Induces a Broadly Cross-Reactive Antibody to Hepatitis C Virus. Hepatology, Vol. 45, No. 4, (April 2007), pp. 911-920, ISSN 0270-9139.

Tribbick, G. (2002) Multipin Peptide Libraries for Antibody and Receptor Epitope Screening and Characterization. J. Immunol. Meth., Vol. 267, No. 1, (September 1, 2002), pp. $27-$ 35, ISSN 0022-1759.

Uchaikin, V.G. \& Shamsheva, O.V. (2001) Vaktsinoprofilaktika (Vaccine Prophylaxis), Moscow: Geotar-Med, 2001.

Urdaneta, M., Prata, A., Struchiner, C.J., Tosta, C.E., Tauil, P., \& Boulos, M. (1998). Evaluation of SPf66 Malaria Vaccine Efficacy in Brazil. Am. J. Trop. Med. Hyg., Vol. 58, No. 3, (March 1998), pp. 378-385, ISSN 0002-9637.

Van Regenmortel, M.H. \& Muller, S. (1999). Synthetic Peptides as Antigens, Elsevier Science, Amsterdam, ISBN 0-444-82176-7. 
Vogel, F.R., \& Alving, C.R. (2002). Progress in immunologic adjuvant development: 1982 2002, In: The Jordan Report, 20th Anniversary. Accelerated Development of Vaccines, C. P.Heilman, P.McInnis, \& S. Landry (Eds.), pp. 39-43, NIH/NIAID (USA).

Voisset, C. \& Dubuisson, J. (2004). Functional Hepatitis C Virus Envelope Glycoproteins. Biol. Cell, Vol. 96, No. 6, pp. 413-420, ISSN 0248-4900.

Volpina, O.M., Gelfanov, V.M., Yarov, A.V., Surovoy, A.Yu., Chepurkin, A V., \& Ivanov, V.T. (1993). New Virus-Specific T-Helper Epitopes of Foot-and-Mouth Disease Viral VP1 Protein. FEBS Lett., vol. 333, No. 1-2, (October 25, 1993), pp. 175-178, ISSN 0014-5793.

Volpina, O.M., Surovoi A.Y., Zhmak, M.N., Kuprianova, M.A., Koroev, D.O., Toloknov, A.S., \& Ivanov, V.T. (1999). A Peptide Construct Containing B-Cell and T-Cell Epitopes from the Foot-and-Mouth Disease Viral VP1 Protein Induces Efficient Antiviral Protection. Vaccine, vol. 17, No. 6, (February, 12, 1999), pp. 1375-1380, ISSN 0264-410X.

Vytvytska, O., Nagy, E., Blüggel, M., Meyer, H.E., Kurzbauer, R., Huber, L.A., \& Klade, C.S. (2002). Identification of Vaccine Candidate Antigens of Staphylococcus aureus by Serological Proteome Analysis. Proteomics, Vol. 2, No.5, (May, 2002), pp. 580-590, ISSN 1615-9853.

Walker, J., Ghosh, S., Pagnon, J., Colantoni, C., Newbold, A., Zeng, W., Jackson, D.C. (2007). Totally Synthetic Peptide-Based Immunocontraceptive Vaccines Show Activity in Dogs of Different Breeds . Vaccine, Vol. 25, No.41, (October 10, 2007), pp. 7111-7119, ISSN 0264-410X.

Wang, T.T., Tan, G.S., Hai, R., Pica, N., Ngai, L., Ekiert, D.C., Wilson, I.A., Garsia-Sastre, A., Moran, T.M. \& Palese, P. (2010). Vaccination with a Synthetic Peptide from the Influenza Virus Hemagglutinin Provides Protection against Distinct Viral Subtypes. Proc. Natl. Acad. Sci. USA, Vol. 107, No. 44, (November 2, 2010), pp.18979-18984, ISSN 0027-8424.

Wiwanitkit, V. (2009). Predicted Epitopes of Malarial Merozoite Surface Protein 1 by Bioinformatics Method: a Clue for Further Vaccine Development. J. Microbiol. Immunol. Infect., Vol. 42, No. 1, (February 2009), pp. 19-21, ISSN 1684-1182.

Worm, M., Lee, H.H., Kleine-Tebbe, J., Hafner, R.P., Laidler, P., Healey, D., Buhot, C., Verhoef, A., Maillère, B., Kay, A.B. \& Larché, M. (2011). Development and Preliminary Clinical evaluation of a Peptide Immunotherapy Vaccine for Cqt Allergy. J. Allergy Clin. Immunol. , Vol. 127, No. 1, (January 2011), pp. 89-97, ISSN 0091-6749.

Wulf, M., Hoehn, P., \& Trinder, P. (2009). Identification and Validation of T-cell Epitopes Using the IFN-gamma ELISPOT Assay. In: Methods Mol. Biol. Vol. 524, No. 4. Epitope Mapping Protocols, M. Schutkowski \& Reineke, U. (Eds.), pp. 361-367, Humana Press, ISBN 978-1-59745-450-6_32.

Yutani S., Komatsu, N. Shichijo, S., Yoshida, K., Hiroko Takedatsu, H., Minoru Itou, M., Kuromatu, R.,Ide, T., Tanaka, M., Sata, M., Yamada, A. \& Itoh, K. (2009). Phase I Clinical Study of a Peptide Vaccination for Hepatitis C Virus-Infected Patients with Different Human Leukocyte Antigen-Class I-A Alleles. Cancer Sci., Vol. 100, No. 10, (October 13, 2009), pp.1935-1942, ISSN 1349-7006. 
Zeng, W., Ghosh, S., Lau, Y.F., Brown, L.E., \& Jackson, D.C. (2002). Highly Immunogenic and Totally Synthetic Lipopeptides as Self-Adjuvanting Immunocontraceptive Vaccines. J. Immunol., Vol. 169, No. 9, (November 1, 2002),pp. 4905-4912, ISSN 0022-1767.

Zeng, W., Jackson, D.C., Murray, J., Rose, K., \& Brown, L.E. (2000). Totally Synthetic LipidContaining Polyoxime Peptide Constructs are Potent Immunogens. Vaccine, Vol. 18, No. 11-12, (January 6, 2000), pp. 1031-1039, ISSN 0264-410X.

Zhu, Q., Oei, Y., Mendel, D.B., Garrett, E.N., Patawaran, M.B., Hollenbach, P.W., Aukerman, S.L., \& Weiner, A.J. (2006). Novel Robust Hepatitis C Virus Mouse Efficacy Model. Antimicrob. Agents Chemother., Vol. 50, No.10, (October 2006), pp. 3260-3268, ISSN 0066-4804. 


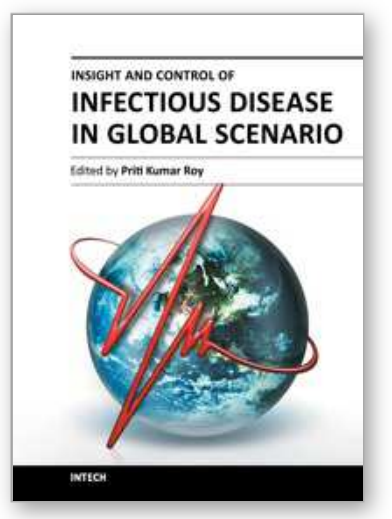

\author{
Insight and Control of Infectious Disease in Global Scenario \\ Edited by Dr. Roy Priti
}

ISBN 978-953-51-0319-6

Hard cover, 442 pages

Publisher InTech

Published online 21, March, 2012

Published in print edition March, 2012

This book is projected as a preliminary manuscript in Infectious Disease. It is undertaken to cover the foremost basic features of the articles. Infectious Disease and analogous phenomenon have been one of the main imperative postwar accomplishments in the world. The book expects to provide its reader, who does not make believe to be a proficient mathematician, an extensive preamble to the field of infectious disease. It may immeasurably assist the Scientists and Research Scholars for continuing their investigate workings on this discipline. Numerous productive and precise illustrated descriptions with a number of analyses have been included. The book offers a smooth and continuing evolution from the principally disease oriented lessons to a logical advance, providing the researchers with a compact groundwork for upcoming studies in this subject.

\title{
How to reference
}

In order to correctly reference this scholarly work, feel free to copy and paste the following:

Alexandr A. Moisa and Ekaterina F. Kolesanova (2012). Synthetic Peptide Vaccines, Insight and Control of Infectious Disease in Global Scenario, Dr. Roy Priti (Ed.), ISBN: 978-953-51-0319-6, InTech, Available from: http://www.intechopen.com/books/insight-and-control-of-infectious-disease-in-global-scenario/syntheticpeptide-vaccines

\section{INTECH}

open science | open minds

\author{
InTech Europe \\ University Campus STeP Ri \\ Slavka Krautzeka 83/A \\ 51000 Rijeka, Croatia \\ Phone: +385 (51) 770447 \\ Fax: +385 (51) 686166 \\ www.intechopen.com
}

\author{
InTech China \\ Unit 405, Office Block, Hotel Equatorial Shanghai \\ No.65, Yan An Road (West), Shanghai, 200040, China \\ 中国上海市延安西路65号上海国际贵都大饭店办公楼 405 单元 \\ Phone: +86-21-62489820 \\ Fax: +86-21-62489821
}


(C) 2012 The Author(s). Licensee IntechOpen. This is an open access article distributed under the terms of the Creative Commons Attribution 3.0 License, which permits unrestricted use, distribution, and reproduction in any medium, provided the original work is properly cited. 